\title{
TRANSACTIONS
}

$$
\text { OF THB }
$$

\section{ROYAL SOCIETY OF EDINBURGH}

\author{
VOL. LXIV-No. 1 \\ 1958-59
}

\section{GLAUCOPHANE-SCHIST, ECLOGITE, AND ASSOCIATED ROCKS FROM KNOCKORMAL IN THE GIRVAN- BALLANTRAE COMPLEX, SOUTH AYRSHIRE}

\author{
BY \\ T. W. BLOXAM, B.Sc., Ph.D., F.G.S., \\ Department of Geology, University College, Swansea \\ AND \\ J. B. ALLEN, B.Sc., Ph.D., F.G.S., \\ Mineral Regources Division, Overseas Geological Surveys, London
}

[With Two Plates, Three Text-figures and Ten Tables]

PUBLISHED BY THE

ROYAL SOCIETY OF EDINBURGH

22 GEORGE STREET

EDINBURGH 2

1960

Price Ten Shillings and Sixpence 